\title{
Giht, suvremeni pogled na drevnu bolest
} Gout, contemporary insight into an ancient disease

\author{
Nadica Laktašić Žerjavići ${ }^{*}$, Nadia Hoteit ${ }^{2}$, Dragica Soldo Jureša ${ }^{3}$
}

\begin{abstract}
Sažetak. Giht je kronična metabolička, no istovremeno i upalna reumatska bolest koja nastaje kao posljedica hiperuricemije i taloženja kristala mononatrijeva urata. Glavni uzrok hiperuricemije je smanjeno bubrežno izlučivanje urata. U patogenezi upalnog odgovora na kristale urata važna je fagocitoza kristala od strane makrofaga koja dovodi do aktivacije inflamasoma NLRP3 i posljedičnog oslobađanja glavnog proupalnog citokina u gihtu interleukina $1 \beta$. Neadekvatno liječenje hiperuricemije dovodi do razvoja kroničnog gihta $s$ tofima, značajnih strukturnih oštećenja zglobova s umanjenom funkcionalnom sposobnosti i kvalitetom života. Stoga je važno dugotrajno liječenje usmjereno k cilju održavanja koncentracije urata $<350 \mathrm{umol} / \mathrm{L}$, a u težem obliku bolesti s tofima $<300 \mathrm{umol} / \mathrm{L}$. Akutni artritis u gihtu i akutizaciju kroničnog gihta treba liječiti protuupalnim lijekovima: nesteroidnim antireumaticima, kolhicinom ili glukokortikoidima, uglavnom po monoterapijskom principu. Pacijente $s$ gihtom treba pažljivo pratiti radi udruženih bolesti, posebice bubrežne bolesti, hipertenzije, metaboličkog sindroma i povišenog kardiovaskularnog rizika.
\end{abstract}

Ključne riječi: giht; hiperuricemija; komorbiditeti; kristalne artropatije

Abstract. Gout is a chronic metabolic but at the same time inflammatory rheumatic disease which develops as a cosequence of increased urate concentration and deposites of monosodium urate crystals. The main cause of hyperuricaemia is renal urate underexcretion. In the pathogenesis of the inflammatory response to urate crystals, the phagocytosis of crystals by the macrophages is important, leading to activation of the NLRP3 inflammasome and the consequent release of the major proinflammatory cytokine interleukin $1 \beta$. Inadequate long-term treatment of hyperuricaemia leads to the development of chronic gout, which causes significant structural joint damage, disability and reduced quality of life. Therefore, long term urate lowering treatment aimed at maintaining urate concentrations < $350 \mathrm{umol} / \mathrm{L}$ in early disease and $<300 \mathrm{umol} / \mathrm{L}$ in chronic tophaceous disease is mandatory. Acute arthritis in gout, or a flaire in chronic arthritis should be treated with anti-inflammatory drugs: non-steroidal anti-inflammatory drugs, colchicine or glucocorticoids, mainly as a monotherapy. Patients with gout should be closely monitored for associated comorbidities, especially renal disease, hypertension, metabolic syndrome, and elevated cardiovascular risk.

Key words: comorbidity; crystal arthropathies; gout; hyperuricaemia

\author{
${ }^{1}$ Medicinski fakultet, Sveučilište u Zagrebu, \\ Klinika za reumatske bolesti i rehabilitaciju, \\ Klinički bolnički centar Zagreb, Kišpatićeva \\ 12, 10000 Zagreb \\ ${ }^{2}$ Medicinski fakultet, Sveučilište u Zagrebu, \\ Šalata 3, 10000 Zagreb \\ ${ }^{3}$ Medicinski fakultet, Sveučilište u Zagrebu, \\ Klinika za dijabetes, endokrinologiju i bolesti \\ metabolizma „Vuk Vrhovac“, Klinička bolnica \\ Merkur, Dugi dol 4a, 10000 Zagreb
}

\section{Dopisni autor:}

Doc. dr. sc. Nadica Laktašić Žerjavić, dr. med. Medicinski fakultet, Klinika za reumatske bolesti i rehabilitaciju Kliničkog bolničkog centra Zagreb, Kišpatićeva 12, 10000 Zagreb e-mail: nadica_laktasic@yahoo.com

http://hrcak.srce.hr/medicina 


\section{UVOD}

Giht je sustavna metabolička bolest taloženja kristala mononatrijeva urata (engl. monosodium urate; MSU) koji nastaju u prisutnosti povećanih koncentracija urata, tj. hiperuricemije. Naslage kristala MSU-a prisutnih u sinovijalnoj tekućini zgloba, na površini zglobne hijaline hrskavice i kosti, u tetivama, burzama i okozglobnim mekim tkivima, izazivaju upalni odgovor, što rezultira ponavljajućim akutnim artritisom. Svaki napad uzro-

Giht je kronična, progresivna bolest koja se može izliječiti trajnim održavanjem koncentracije urata ispod 350 umol/L u ranoj fazi bolesti, te ispod 300 umol/L u razvijenom kroničnom gihtu s tofima.

kuje nepovratno oštećenje zgloba, što u konačnici dovodi do sekundarnog osteoartritisa, smanjene funkcionalne sposobnosti i kvalitete života. Neliječenjem gihta postupno se razvija kronični deformirajući artritis s poliartikularnom prezentacijom, obično nakon razdoblja duljeg od deset godina. Stoga je kamen temeljac u liječenju gihta sprječavanje stvaranja naslaga kristala u ranom stadiju bolesti i postizanja otapanja kristala u uznapredovalom gihtu primjenom lijekova za snižavanje urata (engl. urate lowering therapy; ULT), dok istovremeno u fazama akutizacije artritisa upalu treba brzo suzbiti protuupalnim lijekovi$\mathrm{ma}^{1,2}$.

\section{EPIDEMIOLOGIJA}

Giht je najčešća upalna artropatija s prevalencijom do $4 \%$ u općoj populaciji razvijenih zemalja. Štoviše, prevalencija gihta povećava se posljedično modernom stilu života. Prevalencija je viša kod muškaraca nego kod žena i povećava se $s$ dobi, ali kod žena u svim dobnim skupinama nikad ne dostiže prevalenciju u muškaraca. Kod muškaraca giht se obično javlja između 40. i 50. godine života. Estrogeni potiču izlučivanje urata bubregom, stoga porast prevalencije gihta kod žena nastupa u postmenopauzi, tj. nakon 60. godine života. Do puberteta giht se rijetko javlja kod djece zbog fiziološki niske razine urata u krvi. Rijetki slučajevi gihta kod djece javljaju se uglav- nom kao posljedica malignih bolesti ili kao posljedica genetskog poremećaja kod dječaka. Prevalencija hiperuricemije u općoj populaciji iznosi oko $20 \%$, dok samo 4 - $6 \%$ žena u premenopauzi ima hiperuricemiju ${ }^{3-9}$.

\section{PATOFIZIOLOGIJA GIHTA}

\section{Patofiziologija hiperuricemije}

Mokraćna kiselina je u ljudi krajnji produkt metabolizma purinskih nukleotida adenozina i gvanina koji se uz pomoć enzima ksantin oksidaze metaboliziraju preko hipoksantina i ksantina u urat. Ona je jedan od najvažnijih antioksidansa, snažniji od vitamina C. Ljudi i primati ne posjeduju jetreni enzim urikazu (urat oksidaza) poput većine sisavaca, a koji razgrađuje višak urata u vodi topljivi alantoin. Mokraćna kiselina je slaba organska kiselina koja u fiziološkim uvjetima cirkulira u tjelesnim tekućinama (sinovijalna tekućina i plazma) kao deprotonirani uratni anion, a veže se $s$ ionima natrija kako bi tvorila ionizirani oblik natrijeve uratne soli (MSU monohidrat) u kojem je molekula urata vezana na jednu molekulu natrija i jednu molekulu vode, a čijom kristalizacijom nastaju kristalni depoziti kod gihta. Proces kristalizacije i taloženja urata započinje pri punom zasićenju plazme (koncentracija 408 umol/L (6,8 $\mathrm{mg} / \mathrm{dL}$ ) pri $37^{\circ} \mathrm{C}$ ). Topljivost je loša, tako da je normalna koncentracija urata u krvi vrlo blizu gornjoj granici topljivosti i pod utjecajem je kiselosti $(\mathrm{pH})$ i temperature ${ }^{10}$. U perifernim zglobovima niži je $\mathrm{pH}$ i niža je temperatura tkiva, pa se kristalizacija MSU-a može dogoditi i pri nižoj serumskoj koncentraciji urata (engl. serum uric acid concentration; SUA), npr. pri $35^{\circ} \mathrm{C}$ kristalizacija in vitro nastaje pri SUA od 360 umol/L ${ }^{11}$. Valja napomenuti da je fiziološka temperatura u zglobu koljena između 31 i $33^{\circ} \mathrm{C}^{12}$. Glavni način uklanjanja urata je bubreg kojim se uklanja otprilike dvije trećine (oko $70 \%$ ) urata. U manjoj mjeri urati se eliminiraju putem probavnog sustava, stolicom. Probavni sustav sadrži bakterije koje razgrađuju mokraćnu kiselinu do amonijaka i ugljičnog dioksida, a koji se uklanjaju flatulencijom. Male količine urata uklanjaju se i kroz kožu, kosu, slinu i nokte. U glomerulima se urat gotovo $100 \%$ filtrira, nakon čega slijedi gotovo potpuna reapsorpcija, aktivna sekrecija i djelomična reapsorpcija duž 
tijeka proksimalnog tubula. U konačnici se samo $10 \%$ primarno filtriranog urata izlučuje urinom ${ }^{13}$. Hiperuricemija može nastati kao rezultat prekomjerne proizvodnje urata ili smanjenog izlučivanja urata bubregom ili kao kombinacija oba mehanizma. Najčešći uzrok hiperuricemije je smanjena bubrežna ekskrecija urata koja je posljedica smanjene funkcije bubrega kod bubrežne bolesti ili je smanjena sekundarno uzimanjem nekih lijekova te u rijetkim genetskim poremećajima koji utječu na sekretorne i reapsorptivne proteine $u$ tubularnom transportu urata. Urati nisu liposolubilni, zato im je potreban specifični membranski transporter kroz staničnu membranu. URAT1 je član porodice organskih anionskih transportera (OAT) koji je lokaliziran u apikalnom dijelu endotelnih stanica proksimalnih tubula gdje posreduje ponovnu apsorpciju (reapsorpciju) urata iz tubula u endotelnu stanicu, igrajući ključnu ulogu u homeostazi mokraćne kiseline. Reapsorbirani urat vraća se u krv iz endotelne stanice tubula pomoću drugog transportera, GLUT9. Poremećena aktivnost URAT1 transportera, zbog genskog polimorfizma, može rezultirati hiperuricemijom ili hipouricemijom. Lijekovi kao što su probenecid, sulfinpirazon i benzbromaron smanjuju aktivnost URAT1 transportera i posljedično smanjuju reapsorpciju urata u proksimalnim kanalićima, pa se stoga koriste kao urikozurici. Losartan i atorvastatin također djeluju kao urikozurici. S druge strane, lijekovi kao što je pirazinamid povećavaju aktivnost URAT1 transportera te time pospješuju prijenos urata iz lumena kanalića u stanice proksimalnih kanalića i dovode do hipeuricemije. Neki lijekovi ostvarit će svoj učinak ovisno o njihovoj dozi. Niske doze acetilsalicilne kiseline djelovat će antiurikozurično, tj. smanjit će izlučivanje urata, dok će visoke doze imati suprotan učinak, odnosno povećat će izlučivanje urata. Tiazidski diuretici (hidroklortijazid, klortalidon i indapamid) izravno povećavaju reapsorpciju urata u proksimalnom tubulu korištenjem anionskog izmjenjivača OAT1 na bazalnoj membrani i OAT4 na luminalnoj membrani dovodeći do hiperuricemije. Alkohol (etanol) povećava razgradnju nukleotida adenina i povećava razinu mliječne kiseline u krvi, što dovodi do hiperuricemije. Purini piva dodatno pridonose povećanju mokraćne kiseline u plazmi. Dehidracija i ketoaci- doza (uslijed ubuzusa etanola) povezane su s povećanjem razine mokraćne kiseline u serumu. Olovo i citostatici (ciklosporin) ireverzibilno oštećuju bubrežne tubule $\mathrm{e}^{14,15}$.

Jetra je glavno mjesto sinteze urata. Hrana je odgovorna za samo do $10 \%$ SUA, što znači da prekomjerna proizvodnja urata u jetri kroz put razgradnje egzogeno unesenih purina (ingestijom) malo pridonosi koncentraciji urata u serumu. Najčešći endogeni uzrok prekomjerne proizvodnje urata u jetri i hiperuricemije je povećana pregradnja nukleoproteina tijekom povećane proliferacije i razaranja stanica u hematološkim malignitetima, hemolitičkoj anemiji, psorijazi i tijekom citotoksične terapije tumora ili terapije tumora zračenjem ${ }^{1}$.

\section{Primarni nasljedni poremećaji metabolizma urata}

Pri pojavi hiperuricemije u djece i teškim oblicima gihta u odraslih treba posumnjati na genetski poremećaj u metabolizmu purina. Nedostatak enzima hipoksantin-gvanin-fosforibozil transferaze (HGPRT) povezan je s povišenim SUA, a kompletan nedostatak predstavlja Lesch-Nyhanov sindrom u dječaka, s prevalencijom jedan do dva slučaja na milijun stanovnika, koji se najčešće očituje već u prvoj godini života imitirajući sliku cerebralne paralize, a tipično na pelenama se javlja narančasti talog kristala urata. Radi se o uz X kromosom vezanoj recesivnoj bolesti koja se očituje promjenama na zglobovima tipičnim za urični artritis, bubrežnim kamencima i neurološkim poremećajima, kao što su distonija, koreja, kognitivni poremećaj i poremećaj ponašanja. Težina kliničke slike je različita i ovisi o tipu mutacijie gena na $\mathrm{X}$ kromosomu. Važno je pravovremeno započeti liječenje ULT-om, kako bi se spriječio ili odgodio nastanak tofa te bubrežnog zatajenja. Očekivano trajanje života u ove djece značajno je skraćeno ${ }^{16}$. Sljedeći nasljedni poremećaj metabolizma urata je za $\mathrm{X}$ kromosom vezani dominantni genetski poremećaj kod kojeg mutacija gena za enzim fosforibozil-pirofosfat sintetazu (skr. PRPPS) dovodi do njegove pojačane aktivnosti i posljedično pretjerane de novo sinteze purina. Katabolizmom pretjerano stvorenih purina dolazi do hiperuricemije i nefrolitijaze. Poremećaj se očituje i neurološkim poremećajima, kao što su hipotonija, ataksija te senzorineuralni gubitak sluha koji prethode artritisu $^{17}$. 


\section{Patofiziologija upalnog odgovora na kristale urata}

Prisutnost naslaga kristala urata u zglobnoj šupljini ili njihov prodor iz okolnih tkiva u sinovijalnu tekućinu važan je za pokretanje akutnog upalnog odgovora, koji se očituje akutnim napadom artritisa. Kristali MSU-a izolirani s mjesta upale u gihtu obično su obloženi imunoglobulinima, uglavnom klase IgG, čija se površinska koncentracija smanjuje kako se upala smiruje. Prvi korak u upalnoj kaskadi je da lokalni monociti i makrofazi fagocitiraju kristale MSU-a. Imunoglobulini omogućuju stanicama koje nose Fc-receptor fagocitozu kristala i sljedstvenu staničnu aktivaciju. Nakon fagocitoze dolazi do proteolitičkog cijepanja i aktivacije kaspaze 1 te aktivacije proteinskog kompleksa (inflamasom NLRP3) koji pretvara pro-

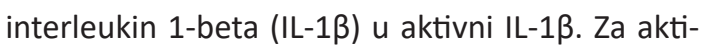
vaciju makrofaga uz fagocitozu kristala MSU-a potrebna je i koaktivacija putem Toll like receptora (engl. toll like receptor; TLR) sa slobodnim masnim kiselinama (npr. kod obilnog obroka ili naglog mršavljenja). Upalni odgovor pojačava se aktiviranjem neutrofila i mastocita, što dovodi do oslobađanja proupalnih citokina i kemokina (interleukin-8, IL-8; faktor tumorske nekroze alfa, TNF $\alpha$ ) i drugih čimbenika kao što su slobodni radikali kisika, prostaglandin E2 i lizosomalni enzimi. Izrazito visoka aktivnost artritisa razvija se $u$ roku od samo nekoliko sati. Spontano stišavanje upale uključuje razgradnju proupalnih molekula i proizvodnju protuupanih citokina, u prvom redu transformirajućeg faktora rasta- $\beta 1$ (TGF- $\beta 1$ ) od strane makrofaga koji fagocitiraju apoptotične neutrofile. Ostali predloženi mehanizmi su stvaranje neutrofilnih ekstracelularnih zamki (engl. neutrophil extracellular trap; NET) i oblaganje kristala MSU-a apolipoproteinom B, što ih čini nedostupnim fagocitozi. Nakon što akutni upalni odgovor prestane, kristali MSU-a i dalje su prisutni, dovodeći do kronične upale niskog stupnja (supklinička upala) i napredovanja oštećenja zglobova, iako je pacijent $u$ toj fazi razvoja gihta prividno zdrav. Lipoproteini niske gustoće (LDL), posebno apolipoprotein B u LDL-u, vežu se na kristale MSU-a stvarajući kristalni omotač i sprječavaju aktiviranje neutrofila i suzbijaju upalu u interkritičkom razdoblju, tj. razdoblju između dva napada akutnog artritisa. Pretpostavlja se da je to i mehanizam koji u rijetkih pacijenata sprječava pojavu artritisa usprkos hiperuricemiji i taloženju kristala MSU ${ }^{18-21}$.

\section{Patofiziologija stvaranja tofa i erozija zglobova i kosti}

NET formacije koje nastaju interakcijom neutrofila s kristalima MSU-a su prekretnica u stvaranju tofa. Tof predstavlja složen i organiziran kronični upalni odgovor tkiva na nataložene kristale MSUa, koji se sastoji od acelularne jezgrene nakupine igličastih kristala, potom tzv. korone neposredno uz središnju kristalnu jezgru i vanjske fibrovaskularne zone. U jezgri su igličasti kristali MSU-a uloženi u matricu lipida, proteina i mukopolisaharida tvoreći centralnu acelularnu zonu tofa koja je okružena s histocitima (monocitima-makrofazima), multinuklearnim orijaškim stanicama tipa stranog tijela, limfocitima i plazma stanicama te fibroblastima. Makrofazi su prisutni unutar zone korone dok su mastociti prisutni sa sličnom gustoćom u zoni korone i fibrovaskularnoj zoni. Plazma stanice su prisutne u velikom broju unutar zone korone. Suprotno tome, neutrofili se rijetko primjećuju u tofu ${ }^{22,23}$. Tof okružen granulomatoznom upalom agresivan je na priležeću hrskavicu i kost. Citokin IL-1 je ključan citokin ne samo u aktiviranju upale, već i u aktivaciji osteoklasta putem aktivatora receptora nuklearnog faktora kappa-B liganda (engl. receptor activator of nuclear factor kappa-B ligand; RANKL), što rezultira osteoklastogenezom, pojačanom aktivnosti osteoklasta i razvojem koštanih erozija ${ }^{24}$. Štoviše, IL-1 iz monocita-makrfaga potiče sintezu i aktivnost matriks metaloproteinaza (MMP) i drugih enzima koji sudjeluju u degradaciji hrskavice $^{25}$. Snažna je povezanost između mekotkivnog tofa s erozijom kosti i unutar-koštanim tofom ${ }^{26,27}$. Radiografske studije ukazuju da taloženje kristala MSU-a može biti prisutno površno na kosti, uz priležeću eroziju kosti i unutar erozije kosti, ali ne opaža se unutar kosti u odsustvu kortikalnog prekida, odnosno erozije kosti, što snažno ukazuje na mehanizam nastanka „izvana prema unutra”, tj. unutarkoštani tofi su posljedica erozije kortikalisa površinskim tofom i njegovim „urastanjem” u kost $^{28}$. 


\section{KOMORBIDITETI U GIHTU}

\section{Zahvaćanje bubrega u gihtu}

Hiperuricemija je najčešće uzrokovana smanjenom bubrežnom funkcijom, no hiperuricemija oštećuje funkciju bubrega čineći proces dvosmjernim. Hiperuricemija predstavlja nezavisni čimbenik rizika za kroničnu bubrežnu bolest ${ }^{29}$. Kod hiperuricemije može doći do taloženja kristala urata i nefrolitijaze. Rizik je veći kod povećanog lučenja, tj. kod povišene urikozurije (> 800 $\mathrm{mg} / 24 \mathrm{~h}$ urinu) i kod smanjene kiselosti mokraće $(\mathrm{Ph}<5,5)$. Oko $20 \%$ pacijenata s gihtom ima nefrolitijazu, a kamenci mogu nastati i prije artritisa te uzrokuju hematuriju, učestale uroinfekcije te nefokolike i opstrukciju ${ }^{30}$. U hiperuricemiji može nastati i nefropatija. Češće je intersticijsko tubularno oštećenje zbog odlaganja kristala urata u tubule i sabirne kanaliće, što dovodi do njihova oštećenja i začepljenja. Rizik je veći u sekundarnoj hiperuricemiji kod akutnog razaranja tkiva (hematološki malignomi uz uvođenje kemoterapije i zračenja u sklopu sindroma lize tumora), pri acidozi i dehidraciji. Začepljenje tubula kristalima uzrokuje akutnu uratnu nefropatiju s oligurijom do anurijom uz prateću izraženu hiperuricemiju i hiperurikozuriju ${ }^{31}$. Rijetko se kristali odlažu u intersticij medule (mikrotofi u meduli) uzrokujući upalu i fibrozu, tj. kronični intersticijski nefritis koji može dovesti do proteinurije, hipertenzije $\mathrm{i}$ kronične renalne insuficijencije. Potonje se obično viđa kod dugotrajnog teškog gihta ${ }^{32}$.

\section{Giht, metabolički sindrom i povišeni kardiovaskularni rizik}

Uočena je povezanost hiperuricemije i metaboličkog sindroma. Pacijenti s gihtom u do $60 \%$ slučajeva imaju metabolički sindrom, tj. $50 \%$ pacijenata je pretilo, $50 \%$ pacijenata ima dislipidemiju, $70 \%$ pacijenata ima povišen krvni tlak, a $30 \%$ šećernu bolest tip 2. Hiperuricemija korelira $s$ indeksom tjelesne mase (engl. body mass index; BMI) i opsegom struka, a adipokin leptin povećava SUA. Oko $70 \%$ pacijenata s gihtom ima kroničnu bubrežnu bolest $\geq 2$. stupnja ${ }^{33}$. Giht je povezan i s povišenim rizikom od srčanog i moždanog uda$\mathrm{ra}^{33,34}$. Rizik od svih komorbiditeta raste s porastom SUA ${ }^{33}$. Čvrsta povezanost hiperuricemije, bubrežnog popuštanja i porasta krvnog tlaka te porasta rizika od kardiovaskularnih bolesti povezuje se s time što hiperuricemija uzrokuje endotelnu disfunkciju krvnih žila te djeluje aterogeno. Također uzrokuje i mikrovaskularno oštećenje bubrega te dovodi do porasta krvnog tlaka tako što aktivira renin-angiotenzin aldosteron sustav. Mokraćna kiselina smanjuje bioraspoloživost endotelnog dušičnog oksida kao antioksidansa, a potiče stvaranje proupalnih citokina IL-1 $\beta$, IL-6, TNF $\alpha$, što sve pridonosi endotelnoj disfunkciji i

Akutni napad artritisa u gihtu ili akutizaciju kroničnog artritisa treba liječiti protuupalnim lijekovima: nesteroidnim antireumaticima, kolhicinom ili glukokortikoidima, u pravilu po monoterapijskom principu.

Pri uvođenju lijekova za snižavanje koncentracije urata u serumu treba istovremeno uvesti profilaksu jatrogeno izazvanih napada gihta, najčešće manjom dozom nesteroidnog antireumatika.

upali te aterogenezi i porastu krvnog tlaka. Odgovarajućim liječenjem hiperuricemije djelujemo protektivno na vaskularni endotel, indirektno djelujemo na krvni tlak te tako smanjujemo kardiovaskularni rizik ${ }^{35,36}$.

\section{Giht i neurološke bolesti}

Giht je udružen i s povećanim rizikom od neuroloških poremećaja kao što su Parkinsonova bolest, Alzheimerova bolest i vaskuarna i nevaskuarna demencija ${ }^{37-39}$.

\section{KLINIČKA SLIKA GIHTA}

Neliječeni giht razvija se kroz nekoliko faza: hiperuricemija bez dokaza taloženja kristala MSU-a ili uričnog artritisa (asimptomatska hiperuricemija), akutni urični artritis, taloženje kristala bez simptomatskog artritisa (interkritičko razdoblje između dviju epizoda akutnog uričnog artritisa) i kronični urični artritis (uznapredovali stadij gihta koji karakteriziraju trajne zglobne smetnje s povremenom akutizacijom i tofi) (slika 1A). Napredovanje od jedne do druge faze može se spriječiti uvođenjem ULT-a ${ }^{1}$. 


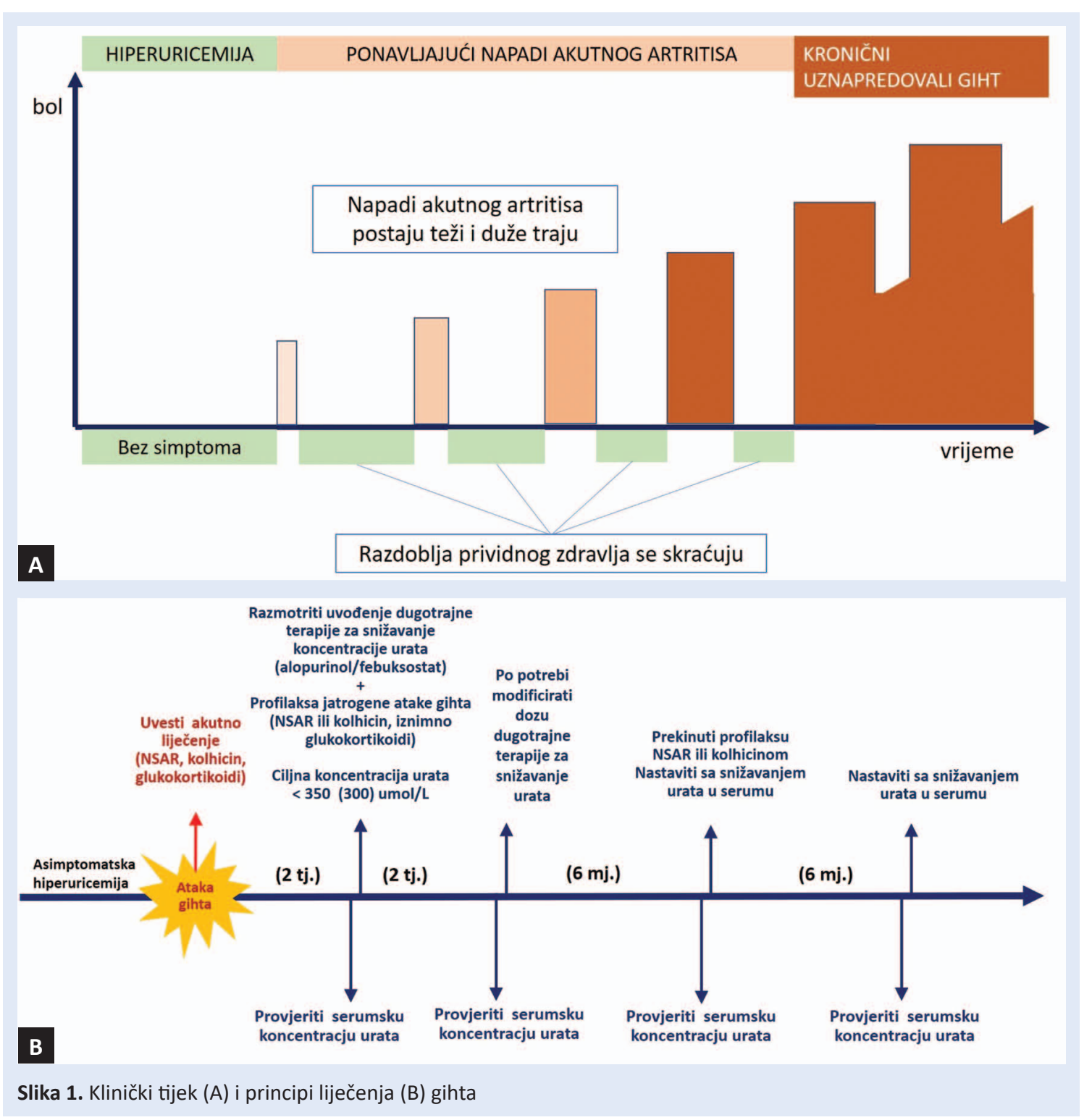

Asimptomatska hiperuricemija prvi je stadij u razvoju gihta tijekom kojeg pacijent nema nikakvih simptoma ni znakova bolesti, no dolazi postepeno do taloženja i akumulacije kristala MSU-a u tkivima. Dio tih pacijenata u budućnosti razvit će urični artritis, a rizik korelira s trajanjem i težinom hiperuricemije i dodatno se povećava s prisutnosti komorbiditeta kao što su pretilost, arterijska hipertenzija i konzumiranjem alkohola ${ }^{40}$. Hiperuricemijom smatramo serumske razine urata iznad referentnih vrijednosti od $360 \mathrm{umol} / \mathrm{L}$ (6,1 mg/ $\mathrm{dL})$ u žena i 428 umol/L (7,2 mg/dL) u muškaraca. Asimptomatska hiperuricemija prestaje s prvom atakom akutnog uričnog artritisa, ili razvojem uratne nefrolitijaze/nefropatije, $a$ obično traje godinama. Započinjanje ULT-a u asimptomatskoj hiperuricemji u pravilu se ne preporučuje, jer je to najčešće dugogodišnja terapija (često i doživotna), pa rizici dugogodišnjeg liječenja u asimptomatskoj hiperuricemji nadvladavaju korist ${ }^{41}$.

Akutni urični artritis je u 90 \% slučajeva monoartikularan (zahvaća jedan zglob), posebice kod prvih napada. Akutni napad gihta je paradigma akutnog artritisa i predstavlja vjerojatno najbolniji oblik akutnog artritisa (vizualna skala bola (VAS bola) u pravilu je $\geq 7$ ). Najčešće se javlja noću ili pred jutro, pri čemu jak i neizdrživ bol budi pacijenta iz sna, a upala je na vrhuncu već nakon 12 do 24 sata. Često i sam pokrivač izaziva nelagodu. Zahvaćeni zglob je crven, otečen, topao, bolan i smanjene pokretljivosti. Tipično upala zahvaća okolna meka tkiva i šira je od područja samog 
zgloba. Prvi napadi se tipično razvijaju na stopalu i to najčešće na prvom metatarzofalangealnom zglobu stopala (MTP 1), što je poznato kao podagra, a od drugih zglobova stopala mogu biti zahvaćeni tarzalni i ostali MTP zglobovi te gležanj. U ponavljajućim napadima akutnog artritisa mogu biti zahvaćeni i koljeno, metakarpofalangealni (MCP) i proksimalni intefalangealni (PIP) zglobovi šaka, ručni zglob, lakat, te olekranonska, prepatelarna i retrokalkanearna burza. Radi uobičajenog crvenila kože poviše zgloba, a posebice u slučaju pojave općih simptoma (češće kod istovremenog zahvaćanja više zglobova) potrebno je isključiti septički artritis (tablica 1 ). Uz prisutnost kristala MSU-a u zglobu ili oko zgloba važni su provocirajući čimbenici za razvoj akutnog napada. Tako, sve što uzrokuje naglu promjenu SUA (bilo da koncentracija naglo raste ili pada) smanjuje topljivost kristala i provocira akutni napad, a to su direktna trauma, interkurentna bolest (posebice s febrilitetom), operativni zahvat (radi prekida unosa tekućine perioperativno i poticanja akutnog upalnog odgovora), dehidracija i acidoza (slučaj kod abuzusa alkohola i mamurluka), brzi gubitak na tjelesnoj težini (gladovanje) te jatrogeni čimbenik, tj. započinjanje terapije hiperurice- mije (nagli pad koncentracije SUA kod uvođenja ULT-a). Prvi napadi najčešće su samolimitirajući i prolaze za 7 - 10 dana i bez terapije ${ }^{1,42}$. U ovoj fazi razvoja gihta najvažnije je protuupalnim lijekovima što brže stišati upalu. Za vrijeme trajanja akutnog napada u pravilu se ne uvodi ULT, a ako je pacijent od ranije uzimao ULT ne mijenja se vrsta i doza lijeka ${ }^{41,43}$.

Interkritičko razdoblje je razdoblje između dvaju napada akutnog artritisa. To je faza kliničke remisije bolesti u kojoj pacijent nema nikakvih tegoba (prividno je zdrav), a može trajati par mjeseci do nekoliko godina, no kristali MSU-a i dalje se talože u sinovijalnoj tekućini, sinovijalnoj membrani i

U pacijenata s gihtom često je prisuta kronična bubrežna bolest, arterijska hipertenzija, hiperlipidemija, šećerna bolest tip 2, pretilost, a povišen je i kardiovaskularni rizik.

Sve pacijente $s$ gihtom treba dijagnostički obraditi radi otkrivanja udruženih bolesti i rizičnih čimbenika za kardiovaskularnu bolest, a njihovo liječenje sastavni je dio liječenja gihta.

Tablica 1. Diferencijalna dijagnoza gihta

\section{KRISTALNE ARTROPATIJE}

\begin{tabular}{|l|l|}
\hline Akutni pseudogiht & $\begin{array}{l}\text { Akutni pseudogiht je kristalna artropatija, no kristali CPPD-a pozitivno su dvolomni u polarizacijskom } \\
\text { mikroskopu (plavi romboidni kristali). Artritis najčešće zahvaća koljeno, ručni zglob i rame. Na RTG-u su } \\
\text { prisutni znaci hodrokalcinoze. Može biti udružen s primarnim hiperparatireoidizmom i ohronozom. }\end{array}$ \\
\hline Septički artritis & $\begin{array}{l}\text { U septičkom artritisu u sinovijalnom aspiratu pozitivan je nalaz ramaza po Gramu i/ili kulture, povećan je } \\
\text { broj stanica (od } 50000 \text { do } 200000 \text { stanica/uL, uglavnom neutrofila), a razina glukoze je smanjena. U } \\
\text { sinovijalnom aspiratu kod gihta također se bilježi porast broja stanica (do oko 50 000), no razina glukoze je } \\
\text { uredna, tj. odgovara onoj u serumu, a ramaz po Gramu i/ili kultura su negativni. Povišene vrijednosti L, CRP } \\
\text { i SE vide se u septičkom artritisu i u gihtu. U septičkom artritisu češće imamo opće simptome kao što je } \\
\text { febrilitet. Kod gihta najčešće nastupi značajno kliničko poboljšanje 24 sata po uvođenju protuupalne doze } \\
\text { NSAR-a. Septički artritis može se razviti u pacijenata s gihtom, pa prisutnost kristala u aspiratu ne isključuje } \\
\text { septički artritis. }\end{array}$ \\
\hline $\begin{array}{l}\text { U reaktivnog artritisa prisutno je crvenilo kože poviše zgloba i najčešće zahvaća zglobove stopala i gležanj, } \\
\text { praćen je porastom L, CRP i SE kao u gihtu, a kultura i razmaz sinovijalne tekućine po Gramu su negativni. }\end{array}$ \\
\hline (ReA) & $\begin{array}{l}\text { Psorijatični artritis zahvaća iste zglobove kao i giht, no nema tofa. Hiperurucemija je česta u psorijazi. } \\
\text { Rame, kralježnica i sakroilijakalni zglobovi obično nisu zahvaćeni u gihtu. Nema izraženog crvenila kože } \\
\text { poviše zgloba kao u gihtu. }\end{array}$ \\
\hline $\begin{array}{l}\text { Psorijatični artritis } \\
\text { (PsA) }\end{array}$ & $\begin{array}{l}\text { Kronični poliartikularni oblik gihta s tofima može nalikovati na RA s reumatoidnim čvorićima. Nema } \\
\text { promjene boje kože poviše zglobova, radiološka slika je drugačija, te je u RA pozitivan RF i/ili anti-CCP. } \\
\text { Ponekad je potrebna biopsija čvora i patohistološka analiza u razlikovanju tofa i reumatoidnog čvorića. }\end{array}$ \\
\hline $\begin{array}{l}\text { Reumatoidni artritis } \\
\text { (RA) }\end{array}$
\end{tabular}

CPPD - kalcij pirofosfat dihidrat, RTG - standardni radiogram, L - leukociti, CRP - C-reaktivni protein, SE - sedimentacija eritrocita, NSAR - nesteroidni antireumatici, RF - reumatoidni faktor, anti-CCP - protutijela protiv citruliniziranih proteina 


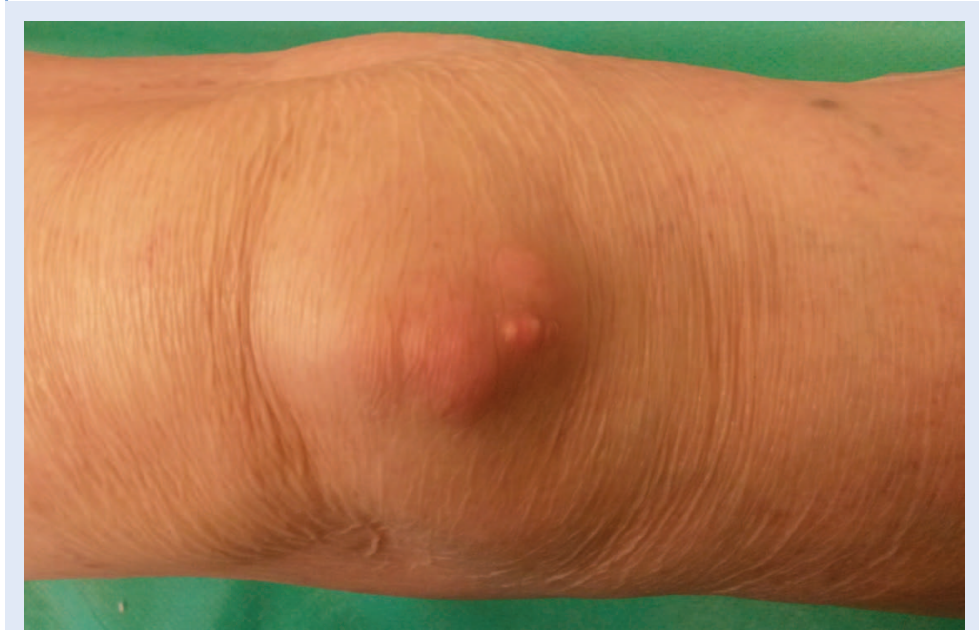

Slika 2. Tof u prepatelarnoj burzi koljena

periartikularnom tkivu, predstavljajući predilekcijsko mjesto za sljedeći napad te uzrokuju supkliničku upalu koja potiho oštećuje zglob. Nakon prvog napada akutnog uričnog artritisa najvažnija je prevencija novih napada i daljnjeg taloženja kristala MSU-a, a to možemo postići jedino kontinuiranom primjenom ULT-a. U neliječenih pacijenata većina nakon prvog napada ima ponavljajuće napade artritisa, do $60 \%$ unutar godine dana, do $80 \%$ unutar dvije godine, a do $90 \%$ unutar 5 godina. Rizik od novog napada artritisa raste sukladno s porastom SUA ${ }^{44}$.

Kronični urični artritis razvija se u neliječene bolesti ili ako terapija za snižavanje koncentracije urata nije zadovoljavajuća. Tada se s vremenom učestalost napada, njihova težina, trajanje i broj zahvaćenih zglobova povećava, a interkritička razdoblja postaju kraća. Nakon prosječno 10 godina razvija se trajno oštećenje zgloba (sekundarni osteoartritis) i bolest postaje oligoartrikularna (zahvaćanje do 4 zgloba) i poliartikularna (zahvaćanje 5 i više zglobova), uz trajno prisutnu upalu, bol, deformaciju zgloba i disfunkciju te pojavu tofa, tj. razvija se kronični giht. U kroničnom gihtu također povremeno dolazi od akutizacije upale. Tada bolest može nalikovati reumatoidnom artritisu s reumatoidnim čvorićima (tablica 1 ). Tofe nalazimo u zglobu na površini hrskavice i kosti, u erozijama kosti, ispod kože u mekom tkivu oko zgloba (najčešće oko 1. MTP zgloba, malih zglobova šake, u olekranonskoj i prepatelarnoj burzi, oko Ahilove tetive), a mogu nastati i ispod kože uha, u bubrezima, srcu i drugim organima.
Prisutnost tofa pokazatelj je kroničnosti i neadekvatnog liječenja. Makroskopski to su najčešće bezbolni čvorovi pod kožom koji bijelo prosijavaju, a mogu ponekad i egzulcerirati, pa se iz njih cijede kristali bijele boje koji izgledom podsjećaju na kredu i rijetko se inficiraju (slika 2). Prisutnost tofa povezana je s razaranjem i deformacijama zgloba te oštećenjem kosti, tj. erozijama. Diferencijalno dijagnostički trebamo pomisliti i na reumatoidne čvoriće u reumatoidnom artritisu, Heberdenove i Bouchardove čvoriće u osteoartritisu (tablica 1). Ponekad je potrebno učiniti biopsiju čvora kako bismo potvrdili da se radi o kristalima MSU-a koji su karakteristični za giht ${ }^{1,42}$. Trajnim održavanjem niske serumske koncentracije urata $<300$ umol/L ( $<5 \mathrm{mg} / \mathrm{dL}$ ) možemo dovesti i do rastapanja tofa i izlječenja gihta. Nije preporučljivo smanjiti SUA < 180 umol/L (< $3 \mathrm{mg} /$ $\mathrm{dL})^{41}$.

\section{DIJAGNOSTIČKI POSTUPCI U GIHTU}

Dijagnoza gihta temelji se na kliničkom nalazu tipičnog napada akutnog artritisa, a definitivna dijagnoza postavlja se dokazom kristala urata u aspiratu sinovijalne tekućine zgloba ili burze (tablica 2). Klasifikacijski kriteriji za giht iz 2015. godine, ACR/EULAR kriiteriji (engl. American College of Rheumatolgy; ACR; engl. European League Against Rheumatism; EULAR) navode 3 glavne grupe kriterija za klasifikaciju gihta ${ }^{45}$. To su ulazni kriterij, dostatni kriterij i dodatni kriteriji. Ulazni kriterij uključuje barem jednu tipičnu epizodu upale koja se očituje oteklinom, bolnošću ili povećanom osjetljivosti perifernog zgloba ili burze. U slučaju zadovoljenog ulaznog kriterija za dijagnozu gihta dostatno je utvrditi prisutnost kristala MSU-a u aspiratu sinovijalne tekućine zgloba, burze ili tofa, što predstavlja tzv. dostatni kriterij. U slučaju da dostatni kriterij nije zadovoljen (nisu dokazani kristali ili pretraga nije učinjena) uz obavezan ulazni kriterij za potvrdu dijagnoze potrebno je sakupiti određeni broj bodova na kliničkim karakteristikama, laboratorijskim pretragama i metodama oslikavanja. Dva kriterija nose negativne bodove zbog toga što njihovo odsustvo uvelike smanjuje vjerojatnost za dijagnozu gihta, a o to je SUA < 250 umol/L i odsutnost kristala MSUa u aspiratu (tablica 2). Prema istraživanjima, di- 
Tablica 2. ACR/EULAR klasifikacijski kriteriji za giht

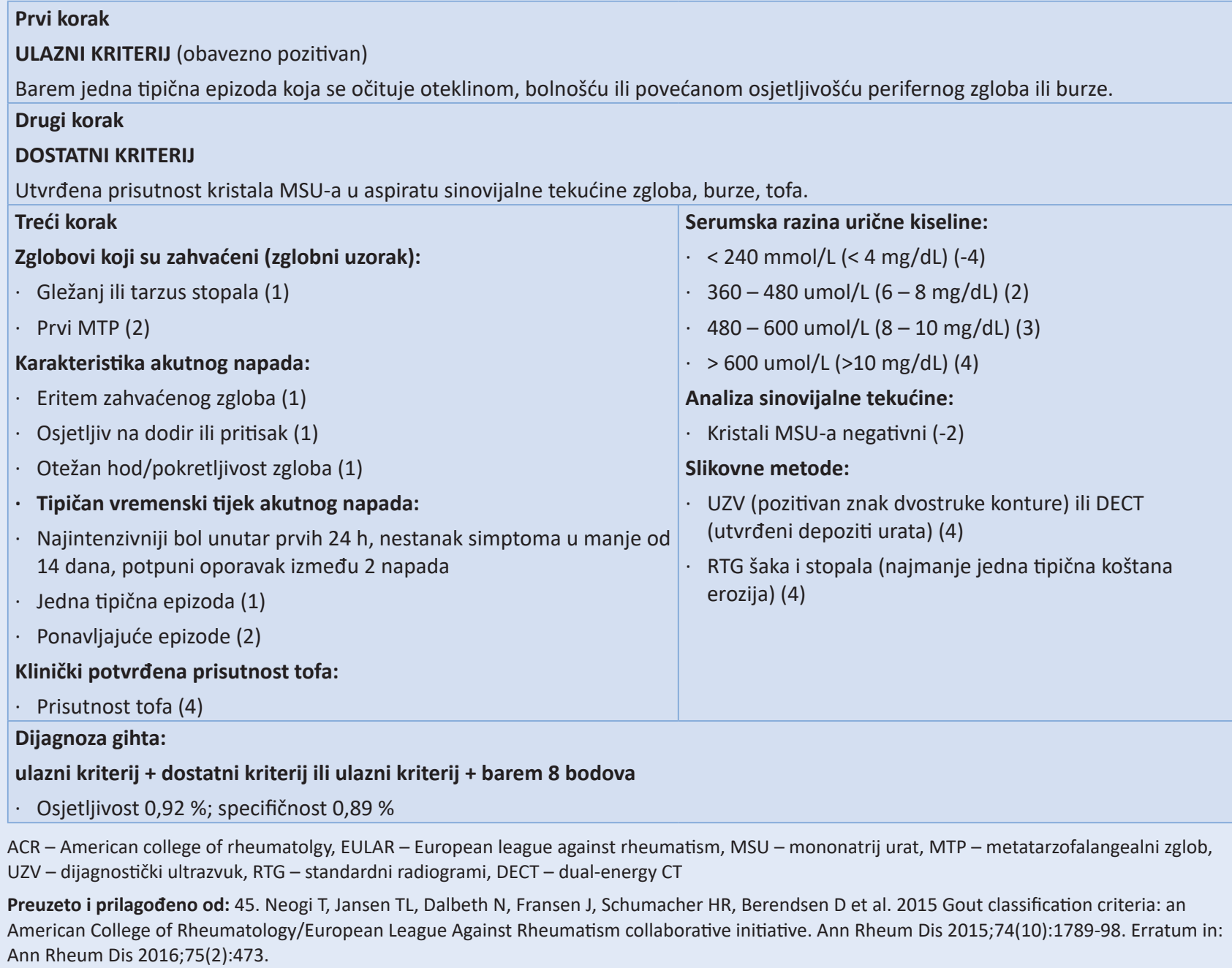

Utvrđena prisutnost kristala MSU-a u aspiratu sinovijalne tekućine zgloba, burze, tofa.

Treći korak

Zglobovi koji su zahvaćeni (zglobni uzorak):

Gležanj ili tarzus stopala (1)

Prvi MTP (2)

\section{Karakteristika akutnog napada:}

Eritem zahvaćenog zgloba (1)

Osjetljiv na dodir ili pritisak (1)

Otežan hod/pokretljivost zgloba (1)

Tipičan vremenski tijek akutnog napada:

Najintenzivniji bol unutar prvih 24 h, nestanak simptoma u manje od 14 dana, potpuni oporavak između 2 napada

Jedna tipična epizoda (1)

Ponavljajuće epizode (2)

Klinički potvrđena prisutnost tofa:

Prisutnost tofa (4)

Dijagnoza gihta:

ulazni kriterij + dostatni kriterij ili ulazni kriterij + barem 8 bodova

- Osjetljivost 0,92\%; specifičnost 0,89\%

ACR - American college of rheumatolgy, EULAR - European league against rheumatism, MSU - mononatrij urat, MTP - metatarzofalangealni zglob, UZV - dijagnostički ultrazvuk, RTG - standardni radiogrami, DECT - dual-energy CT

Preuzeto i prilagođeno od: 45. Neogi T, Jansen TL, Dalbeth N, Fransen J, Schumacher HR, Berendsen D et al. 2015 Gout classification criteria: an American College of Rheumatology/European League Against Rheumatism collaborative initiative. Ann Rheum Dis 2015;74(10):1789-98. Erratum in: Ann Rheum Dis 2016;75(2):473.

Serumska razina urične kiseline:

- $<240 \mathrm{mmol} / \mathrm{L}$ (< $4 \mathrm{mg} / \mathrm{dL})(-4)$

$360-480 \mathrm{umol} / \mathrm{L}(6-8 \mathrm{mg} / \mathrm{dL})(2)$

$480-600 \mathrm{umol} / \mathrm{L}(8-10 \mathrm{mg} / \mathrm{dL})(3)$

- $>600 \mathrm{umol} / \mathrm{L}$ (>10 mg/dL) (4)

Analiza sinovijalne tekućine:

Kristali MSU-a negativni (-2)

Slikovne metode:

UZV (pozitivan znak dvostruke konture) ili DECT (utvrđeni depoziti urata) (4)

RTG šaka i stopala (najmanje jedna tipična koštana erozija) (4)

jagnostički ultrazvuk (UZV) i dvostrukoenergetska kompjutorizirana tomografija (engl. dual energy computed tomography; DECT) najbolje su slikovne metode u dijagnostici uratnih depozita u tkivima te su uvrštene u klasifikacijske kriterije za giht $^{45}$.

Laboratorijska dijagnostika važna je za utvrđivanje hiperuricemije, povišenih upalnih parametara u akutnom artritisu, procjenu bubrežne funkcije i utvrđivanje komorbiditeta.

lako je hiperuricemija jedna od karakteristika gihta, važno je naglasiti da tijekom akutnog napada najčešće dolazi do pada SUA na normalnu razinu. Zbog toga se u dijela pacijenata dijagnoza gihta postavlja uz normalne SUA. Mjerenje urikozurije u 24-satnom urinu je podložno pogrešci. Umjesto toga može se izračunati odnos između klirensa urata i kreatinina izražen kao postotak. To je po- stotak filtriranog urata koji je u konačnici izlučen urinom, a iznosi normalno $7-10 \%$. Uzme se uzorak krvi i urina istovremeno i izračuna se prema formuli: urat $u$ urinu $\mathrm{x}$ kreatinin u serumu / urat $u$ serumu $x$ kreatinin $u$ urinu. Tijekom akutnog napada u krvnoj slici nalazimo povišene vrijednosti leukocita (L), C-reaktivnog proteina (CRP) i ubrzanu sedimentaciju eritrocita (SE) čije vrijednosti mogu biti vrlo visoke. Zlatni standard u dijagnostici je dokaz kristala MSU-a u aspiratu sinovijalne tekućine. Na običnom svjetlosnom mikroskopu kristali MSU-a izgledaju poput iglica, a u polarizacijskom svjetlosnom mikroskopu pokazuju negativnu dvolomnost, tj. svijetle žuto kada su postavljeni paralelno, a plavo kada su postavljeni okomito na smjer polariziranog svjetla. Kristali MSU-a mogu se pronaći u sinovijalnoj tekućini tijekom svih faza gihta, no u fazi akutne 
Tablica 3. Dijagnostički ultrazvuk u gihtu

\section{NESPECIFIČAN ULTRAZVUČNI NALAZ (ukazuje na upalu zgloba, tj. sinovitis i posljedične strukturne promjene zgloba)}

IZLJEV U ZGLOBU - može biti potpuno anehogen ili sadržavati depozite različite ehogenosti. Depoziti kristala MSU-a prikazuju se hiperehogeno te obično plutaju u zglobnom prostoru. Pri blagom pritisku na površinu kože nastaje tzv. fenomen snježne mećave.

SINOVIJALNA PROLIFERACIJA I HIPERVASKULARIZACIJA - primjenom doplera imamo uvid u vaskularizaciju i protok krvi u tkivu, pa tako možemo prikazati aktivnu sinovijanu upalu. Dopler ima važnu ulogu u praćenju bolesti i odgovora na terapiju.

EROZIJE KOSTI - prikazuju se kao intraartikularne ili ekstraartikularne nepravilnosti koštane površine. Predstavljaju prekid kontinuiteta površine kosti širine od najmanje $1 \mathrm{~mm}$ koji se prikazuje u dvije okomite projekcije i ima dno. Češće se nađu u pacijenata s učestalim napadima i dugogodišnjom bolesti s tofima. Unutar erozije može biti smješten intraosealni tof. Osjetljivost ultrazvuka za detekciju erozija $<2 \mathrm{~mm}$ je trostruko veća nego u konvencionalne radiografije.

\section{SPECIFIČAN ULTRAZVUČNI NALAZ (ukazuje na urični artritis)}

DEPOZITI KRISTALA MSU-A NA POVRŠINI ZGLOBNE HRSKAVICE - tzV. „znak dvostruke konture“ vidljiv je kao linearni hiperehogeni depozit kristala na površini hijaline hrskavice koji prati ehogenu liniju površine kosti i specifičan je za giht, tj. ne nalazi se u drugim bolestima. Prisutan je u pacijenata s asimptomatskom hiperuricemijom i tijekom akutnog napada.

TOFI - prikazuju se kao ograničene, heterogene hiperehogene i/ili hipoehogene, nehomogene formacije, ovalna ili nepravilna oblika, često s anehogenim rubom, a mogu dati djelomičnu dorzalnu akustičnu sjenu. Obično pokazuju pozitivan doplerski signal koji ukazuje na upalu, a nalaze se intrartikularno, periartikularno uz tetive i u burzama te supkutano.
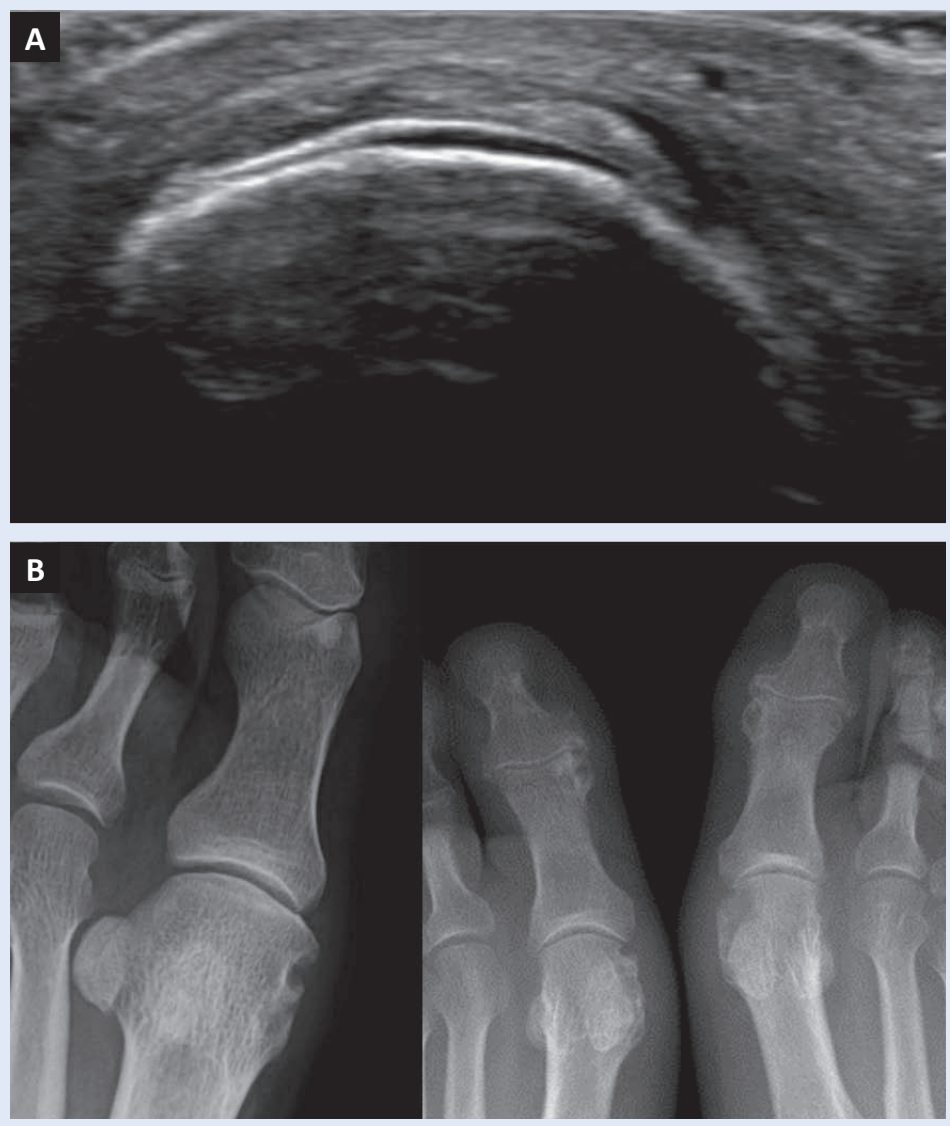

Slika 3. Karakteristični nalaz gihta metodama oslikavanja

Ultrazvučni znak dvostruke konture na pokrovnoj hrskavici glavice metatarzalne kosti prikazuje se kao grubi, linearni, hiperehogeni odjek naslaga kristala urata na površini hijaline hrskavice koji prati ehogeni odjek površine suphondralne kosti (A). Tipične erozije kosti na standardnom radiogramu prvog metatarzofalangealnog i interfalangealnog zgloba palca stopala definirane kao kortikalni defekt sa sklerotičnim, nadsvođenim rubom uz pridružene sekundarne degenerativne promjene (B). upale nalaze se tipično unutar leukocita, stoga uzorak sinovijalne tekućine najbolje je analizirati unutar prvih 6 sati od uzimanja, ili unutar 24 sata ako se čuva u hladnjaku na temperaturi od $4{ }^{\circ} \mathrm{C}$. Budući da je giht često udružen s metaboličkim sindromom, svim pacijentima potrebno je procijeniti kontrolu glikemije, učiniti lipidogram te procijeniti bubrežnu funkciju i vrijednosti krvnog tlaka.

Radiološka dijagnostika ima važnu ulogu u postavljanju dijagnoze i daljnjem praćenju pacijenata.

Dijagnostički ultrazvuk korisna je metoda oslikavanja u gihtu jer može prikazati akutnu upalu zgloba s izljevom, hipertrofiju sinovije s hipervaskularizacijom, erozije i sekundarne degenerativne promjene, no to su sve nespecifične promjene koje se mogu naći i u drugim oblicima artritisa (tablica 3). Specifična promjena koja se vidi na UZV-u je tzv. znak dvostruke konture koji odražava grube depozite kristala MSU-a na površini hijaline hrskavice zgloba (slika 3A). Treba ih tražiti na glavicama MT i MC kosti (posebice MTP1, MCP2, MCP3), kondilima bedrene kosti u koljenu, tijelu talusa u gležnju i glavi nadlaktične kosti u ramenu. Ultrazvukom se mogu prikazati i tofi ${ }^{46}$.

Konvencionalna radiografija najčešće je korištena metoda oslikavanja u kliničkoj praksi, no u većine pacijenata prođe i više od deset godina od prvog napada do pojave prvih radioloških promjena na konvencionalnom radiogramu. Karakte- 
ristične promjene su depoziti kristala MSU-a na površini hrskavice i unutar zgloba i u okozglobnim mekim tkivima (tofi) koji se vide kao gusti čvorovi mekog tkiva i koji su često kalcificirani. Sužavanje zglobnog prostora i suphodralna skleroza te rubni osteofit znaci su sekundarnih degenerativnih promjena zgloba. Erozije su prisutne intraartikularno i/ili jukstaartikularno (slika 3B). Tipično su sklerotičnog ruba i koštano nadsvođene te se ponekad nalaze jedna nasuprot drugoj na oba zglobna tijela, kao da se ljube. Često su vidljive u blizini tofa, s obzirom na to da nastaju kao posljedica urastanja tofa u unutrašnjost kosti. Za razliku od RA očuvana je pariartikularna mineralizacija kosti koja je u RA smanjena i u RA erozije su samo intraartikularne ${ }^{26,47}$.

Kompjutorizirana tomografija (engl. Computed Tomography; CT) je zbog svoje visoke kontrastne osjetljivosti i rezolucije korisna radiološka pretraga u dijagnostici i procjeni kristalnih artropatija, no radi cijene i zračenja koristi se rijetko. Negativna strana je što u ranim fazama gihta ne može detektirati mekotkivne upalne promjene poput sinovitisa, za razliku od dijagnostičkog UZV-a i magnetske rezonancije (MR). CT u kroničnom gihtu ima važnu ulogu te pomoću njega možemo dobro uočiti koštane erozije i tofe. Koštane erozije prikazuju se kao rupičaste litičke lezije s jasno definiranim rubovima uz okolnu sklerotičnu kost. Intraartikularni i intraosealni tofi prikazuju se kao mekotivne mase $s$ naglašenom atenuacijom i time olakšavaju razlikovanje tofa od drugih mekotkivnih lezija ${ }^{48}$.

DECT je novija slikovna metoda koja se koristi u dijagnostici gihta. Radi se o neinvazivnoj i brzoj metodi koja može identificirati i vrlo male depozite kristala MSU-a na temelju njihovog karakterističnog atomskog broja, gustoće i energije fotona ${ }^{27,28}$.

Magnetska rezonancija korisna je u prikazu sinovitisa, erozija, edema kosti, tofa, ali zbog visoke cijene nema široku primjenu. Tofi se na T1 snimci prikazuju kao homogene strukture niskog signala, a na T2 kao heterogene, intermedijarnog do visokog intenziteta signala ${ }^{48}$.

\section{Diferencijalna dijagnoza gihta}

Akutni artritis u gihtu važno je razlikovati od celulitisa, septičkog artritisa i pseudogihta, a kronični od RA-a; u RA-u često postoje reumatoidni čvorići te psorijatičnog artritisa (PsA), jer u PsA četo postoji hiperuricemija (tablica 1).

\section{LIJEČENJE GIHTA}

\section{Opći principi}

U pravilu medikamentozno liječenje hiperuricemije treba započeti tek kada hiperuricemija prijeđe iz asimptomatske u simptomatsku fazu (pojava artritisa) po smirivanju akutnog napada gihta, no liječnik može odlučiti liječiti i asimptomatsku hiperuricemiju. Indikacije za primjenu lijekova koji snižavaju razinu urata u gihtu su: učestali napadi akutnog artritisa ( $\geq 2$ godišnje), prisutnost uratne artropatije, tofa ili bubrežnih kamenaca. Neposredno po postavljanju dijagnoze gihta, tj. već nakon prvog napada akutnog artritisa, lijekove koji snižavaju razinu urata $u$ serumu treba uvesti u slučaju: hiperuricemije $\geq$ 480 umol/L, u osoba mlađih od 40 godina, s obzirom na to da su u njih češći napadaji, te u slučaju prisutnosti komorbiditeta, tj. uz pridruženu kardiovaskularnu i/ili bubrežnu bolest. Liječenje se provodi usmjereno k cilju (engl. Treat to Target; T2T), tj. doza ULT-a postepeno se prilagođava do postizanja serumske koncentracije urata < 350 umol/L u svih pacijenata s gihtom te $<300$ umol/L u pacijenata s teškim oblikom gihta, a na navedenoj razini održava se trajno kao dugogodišnja, kronična terapija. Ne preporučuje se sniziti urate < 180 umol/L, zbog toga što urična kiselina ima neuroprotektivan učinak i djeluje kao antioksidans. U akutnom napadu artritisa nastoji se brzo stišati upala i umanjiti bol protuupalnim lijekovima, najčešće po monoterapijskom principu, nesteroidnim antireumaticima (NSAR), glukokortikoidima, kolhicinom i iznimno IL-1 blokatorom (slika 1B). U akutnom napadu bolan i otečen zglob treba rasteretiti, a lokalno se može primjenjivati hladnoća u svrhu umanjenja bola i upale ${ }^{41}$. U pravilu, ako pacijent nije uzimao od ranije ULT (npr. alopurinol ili febuksostat) ona se uvodi tek po smirivanju akutnog napada gihta, a ako je pacijent uzimao ULT od ranije, tj. prije nastupa akutnog napada gihta, nastavlja se ULT bez promjene doze i vrste lijeka. Po smirivanju akutnog napada gihta uvodi se ili modificira doza ULT-a i uzima se trajno s ciljem prevencije novih napada i razvoja kroničnog gihta. $U$ početku se SUA provjerava svaka 2 do 4 tjedna i doza 
ULT-a se titrira, a nakon uspostavljanja ciljnog SUA pacijente je potrebno pratiti svakih 6 mjeseci i ne prekidati ULT (slika 1B). Uz ULT uvodi se i profilaktički manja doza protuupalnog lijeka (najčešće NSAR ili kolhicina, a samo iznimno glukokortikoida) kroz prvih 6 mjeseci od uvođenja u svrhu prevencije jatrogeno izazvanog napada gihta. U iznimnim slučajevima profilaksa može biti kraća (3 mj.), odnosno najmanje dok se ne odredi stabilna doza lijeka za snižavanje koncentracije urata u serumu (slika 1B). U kroničnom gihtu najvažnije je kontinuirano uzimati ULT jer giht se može izliječiti rastapanjem kristala, eliminiranjem tofa i preveniranjem daljnjeg stvaranja kristala urata i akutnih napada, no sekundarne degenerativne promjene zglobova i erozije zglobova su ireverzibilne promjene. Osobama $s$ formiranim tofima potrebno je i duže vrijeme od $6 \mathrm{mj}$. da se depoziti potpuno otope, tako da i profilaksu treba provoditi kroz duži period. Sve pacijente treba educirati o bolesti i principima medikamentoznog liječenja te savjetovati o promjeni načina života (odgovarajuća dijeta, reguliranje tjelesne težine i umjerena tjelesna aktivnost). Pacijenti trebaju piti veće količine vode i, ako je moguće, izbjegavati lijekove koji smanjuju lučenje urata iz organizma kao što su tiazidski diuretici i statini, osim atorvastatina. Liječenje komorbiditeta sastavni je dio liječenja gihta. $U$ liječenju hiperlipidemije prednost imaju atorvastatin (radi urikozuričkog djelovanja) i fenofibrat te u liječenju hipertenzije losartan (radi urikozuričkog djelovanja) i blokatori kalcijskih kanala ${ }^{41}$. U pacijenata s gihtom i hiperuricemijom mlađa dob, viši BMI i viša početna vrijednost SUA prediktori su slabog odgovora na ULT. Takvim pacijentima treba pružiti posebnu pozornost i individualizirani pristup ${ }^{49}$.

Protuupalni lijekovi

Nesteroidni antireumatici u pravilu su prvi lijek izbora u liječenju akutnog napada gihta, zbog svog snažnog protuupalnog i analgetskog djelovanja koje se ostvaruje blokiranjem enzima ciklooksigenaze (COX) i posljedično sinteze prostaglandina. U prvih nekoliko dana u akutnom napadu artritisa (prva 2 - 3 dana) primjenjuju se u maksimalnoj dozi (npr. indometacin $3 \times 50 \mathrm{mg} /$ dan), a potom u protuupalnoj dozi do smirivanja tegoba (npr. indometacin $3 \times 25 \mathrm{mg} /$ dan). Uvijek ih je potrebno uzimati uz obrok i po potrebi uzeti inhibitor pro- tonske pumpe (npr. pantoprazol) radi gastroprotekcije. Standardni i COX-2 selektivni (tzv. kosibi) NSAR podjednako su učinkoviti u liječenju gihta. Najčešće se daje indometacin zbog svog snažnog protuupalnog djelovanja. U pacijenata s povećanim gastrointestinalnim rizikom prednost imaju kosibi. U pacijenata s povišenim kardiovaskularnim rizikom treba biti oprezan jer svi NSAR mogu dovesti do zadržavanja vode i soli te edema i porasta krvnog tlaka i pogoršati srčano popuštanje, a koksibi (celekoksib i etorikoksib) i diklofenak mogu dodatno povećati rizik od tromboembolijskih incidenata (infakta miokarda). Najbolji učinak ostvaruju ako se uzimaju već pri pojavi prvih simptoma i zato je važna edukacija pacijenata. U profilaksi jatrogenog napada gihta NSAR se primjenjuju u manjoj dozi (npr. indometacin $2 \times 25$ $\mathrm{mg} /$ dan ili naproksen $2 \times 250 \mathrm{mg} /$ dan) $)^{1,18,41}$.

Glukokortikoidi, najčešće prednizolon u oralnom obliku, potencijalna su prva linija u liječenju akutnog uričnog artritisa ako su NSAR kontraindicirani zbog rizika od krvarenja iz gornjeg dijela gastrointestinalnog trakta, kardiovaskularnog rizika, izraženog bubrežnog popuštanja ili preosjetljivosti na NSAR. Primjenjuju se u dnevnoj dozi od $30-35$ $\mathrm{mg}$ prednizolona (5 $\mathrm{mg}$ prednizolona $=4 \mathrm{mg}$ metilprednizolona), $\mathrm{tj}$. oko $0,5 \mathrm{mg} / \mathrm{kg}$ tjelesne mase kroz 3 do 5 dana uz potom brzu redukciju doze i ukidanje nakon ukupno 10-ak dana. Glukokortikoidi su vrlo učinkoviti, no mogu dovesti do poremećene kontrole krvnog tlaka i glikemije. Uz oralni prednizolon, glukokortikoidi se mogu se primjenjivati i intraartikularno te intrabuzalno ${ }^{1,18,41}$.

Kolhicin predstavlja alkaloid šafrana, ulazi u neutrofile, mijenja njihov motilitet i adhezivne sposobnosti, inhibira fosfolipazu A2 te tako inhibira stvaranje prostaglandina i leukotriena te inhibira fagocitozu. Danas se rjeđe koristi u liječenju akutnog napada gihta zbog nuspojava. Ima dobar učinak ako se uzme unutar 12 sati od izbijanja simptoma. Proizvodi se u tabletama od 0,5 i 0,6 $\mathrm{mg}$, pa su preporuke da se u tom slučaju uzme 1 $(1,2) \mathrm{mg}$ kolhicina odmah i 0,5 $(0,6) \mathrm{mg}$ nakon 1 sat te potom nastavlja s $2 \times 0,5(0,6) \mathrm{mg}$ kroz 7 14 dana. Ako simptomi traju duže od 12 sati, učinkovitost kolhicina je mnogo manja, pa ga ne treba davati pacijentima u kojih simptomi traju duže od 12 i 24 sata. Nuspojave uz primjenu kol- 
hicina dosta su česte i većinom potječu od gastrointestinalnog sustava (proljev, povraćanje i mučnina). Zbog uske terapijske širine, pojava neke od nuspojava upućuje na povišene sistemske koncentracije kolhicina, te zahtijeva smanjenje doze ili potpuni prekid. Lijek je potencijalno nefrotoksičan i mijelotoksičan. Ozbiljnije nuspojave koje se mogu javiti uključuju neutropeniju i višeorgansko zatajenje, što može završiti smrtnim ishodom. Najčešće je dovoljno 1 - 2 mg kolhicina da se smiri napadaj, no kojiput su potrebne i veće doze, ovisno o pacijentovoj dobi. U pacijenata $\mathrm{s}$ umjerenim bubrežnim zatajenjem potrebno je smanjiti dozu na 0,5 $(0,6) \mathrm{mg} /$ dan, dok je u pacijenata u završnoj fazi zatajenja bubrega kontraindiciran. Dozu bi također trebalo smanjiti u pacijenata sa zatajenjem jetre. Lijekovi koji inhibiraju citokrom P450 3A4 povećavaju plazmatske koncentracije kolhicina i time povećavaju njegovu toksičnost. Ne preporučuje se davati zajedno sa ciklosporinom, ketokonazolom i klaritromicinom. Primjena kohlicina uz statine može se očitovati mišićnom toksičnošću i dovesti do rabdomiolize, osobito u pacijenata s bubrežnim zatajenjem, pa se ne preporučuje njegova primjena s hiplipemicima. U profilaksi jatrogenih ataka primjenjuje se u dozi 1 do 2 x 0,5 $(0,6) \mathrm{mg} /$ dan $^{1,18,41}$.

Blokatori IL-1 indicirani su u liječenju akutnog napada i to samo u pacijenata s teškim i učestalim napadima gihta (barem 3 napada u prethodnih godinu dana) u kojih postoji kontraindikacija za NSAR, glukokortikoide i kolhicin. Europska medicinska agencija (EMA) na temelju kliničkih istraživanja odobrila je 2013. godine primjenu biološkog lijeka canakinumab (dugodjelujućeg monoklonskog protutijela na IL-1 $\beta$ ) u terapiji akutnog napada gihta. Canakinumab se primjenjuje u jednoj dozi dnevno od $150 \mathrm{mg}$ u obliku injekcije za supkutanu primjenu. Neki radovi navode da je i anakinra (biološki lijek, antagonist IL-1 receptora, primarno razvijan i odobren za liječenje RA-a) učinkovita u smanjenju bola i upale kod akutnih napada ako se primjenjuje supkutano u dozi od 100 mg tijekom 3 dana, ali nema još dovoljno istraživanja, tako da anakinra nema odobrenje EMA-e za liječenje gihta. Prema smjernicama IL-1 blokatori su kontraindicirani u osoba s akutnom infekcijom, zbog povećanog rizika od komplikacija, uključujući i sepsu $u^{1,18,41}$.

\section{Terapija s ciljem smanjenja koncentracije urata u serumu - ULT terapija}

Dijeta ima ograničenu mogućnost smanjivanja razine urata u krvi (do $10 \%$ ), no pacijenta treba upozoriti da svaka nagla promjena koncentracije urata, bilo da naglo poraste (neumjerenost u jelu i piću, dehidracija) ili se smanji (gladovanje), smanjuje topljivost urata i može dovesti do provokacije napada gihta. Pacijenti bi trebali uzimati najmanje 2 litre tekućine dnevno. Konzumiranje mesa (RR 1,41) i plodova mora (RR 1,51) povećava rizik od gihta. Povrće poput leće, graška, graha i gljiva također sadrži veće količine purina, ali ne povisuje rizik za razvoj hiperuricemije i gihta (RR $0,96)$ te je dozvoljeno u pacijenata s hiperuricemijom i gihtom. Gotovi voćni sokovi i čajevi, tzv. meki napitci bez alkohola (engl. soft drinks) (RR $1,85)$, pivo (RR 2,51) i žestoka pića (RR 1,60$)$ značajno povećavaju rizik od gihta. Rizik od razvoja gihta manji je u osoba koje konzumiraju puno mliječnih proizvoda u odnosu na one koji konzumiraju malo (RR 0,56) kao i u onih koji uzimanju vitamin C (RR 0,55), pa su mliječni proizvodi i prirodni cijeđeni voćni sokovi dozvoljeni u pacijenata $s$ gihtom. Pacijentima se stoga preporučuje konzumiranje manje količine bijelog mesa i bijele ribe, svog svježeg voća i svog povrća, mlijeka i mliječnih proizvoda, prirodnih voćnih sokova, negazirane vode, nezaslađenog ili blago zaslađenog čaja i kave, a dozvoljene su tek male količine vina. Izbjegavati treba gazirane i gotove voćne napitke, pivo i žestoka pića, tamno meso, suhomesnate proizvode i iznutrice, plavu ribu, rakove i školjke. Hranu treba pripremati na pari i kuhanu ili pečenu s manje masnoća, jer masna hrana povećava rizik od gihta. Potrebno je pacijente upozoriti na izbjegavanje neumjerenosti u jelu i piću te gladovanja $^{1,41,50}$.

Alopurinol je je inhibitor ksantin oksidaze, odnosno urikostatik i prvi je lijek izbora u svim oblicima hiperuricemije $u$ pacijenata $s$ urednom bubrežnom funkcijom. Smanjuje razinu urata u krvi i urinu tako što smanjuje i ukupnu produkciju purina jer utilizira fosforibozil-pirososfat transferazu, enzim koji sudjeluje u sintezi purina de novo. Nakon oralnog unosa, brzo prelazi u aktivni oblik, oksipurinol pomoću enzima ksantin oksidaze. Izlučivanje oksipurinola je većinom putem bu- 
brega, te je potrebno titriranje u pacijenata $\mathrm{s}$ bubrežnom insuficijencijom. Uz primjenu tog lijeka nužno je piti puno tekućine kako bi se spriječilo taloženje ksantina i stvaranje ksantinskih kamenaca u urinarnom traktu. Zbog dugog poluživota, dovoljno je jednom dnevno uzimati Alopurinol. Važno je naglasiti da liječenje treba započeti niskom dozom alopurinola od $100 \mathrm{mg} /$ dan te potom postepeno povećavati dozu za 100 mg svakih 2 do 4 tjedna pri procijenjenoj glomerularnoj filtraciji (eGF) $\geq 60 \mathrm{ml} / \mathrm{min}$ po $1,73 \mathrm{~m} 2$. U bubrežnoj bolesti s eGF $<60 \mathrm{~mL} / \mathrm{min}$ po $1,73 \mathrm{~m} 2$ liječenje treba započeti $s$ dozom alopurinola od $50 \mathrm{mg} /$ dan i dozu lijeka treba povećavati za 50 mg svakih 2 do 4 tjedna dok se ne postigne ciljana uricemija. Najčešće je potrebno barem 300 mg/dan (tj. 1 x 300 mg/dan) alopurinola za postizanje serumske koncentracije urata < 350 umol/L. Zbog promjene životnih navika kontrola uricemije se sve teže postiže, tako da je u pojedinih pacijenata potrebno povećati do maksimalno do 600 (najviše 800 - 900) mg/dan u slučaju da je očuvana bubrežna funkcija uz pravilo da se doza lijeka diže postepeno i brižljivo prati pacijent. Najčešće pogreške u uzimanju su da se daje hipodozirano $i$ umjesto u jednoj dnevnoj dozi podijeljeno u više doza. Uzimanje alpurinola djeluje kardioprotektivno (smanjuje rizik od infarkta miokarda za $20 \%)$. Uz alopurinol i ostale inhibitore ksantin oksidaze ne smije se uzimati azatioprin ili 6-merkaptopurin (povećava koncentraciju azatioprina). Nuspojave su dosta rijetke, ali moguće, kao što su mučnina, proljev, jetrena toksičnost, toksičnost na koštanu srž i rijetko akutni intersticijski nefritis. U nekih pacijenata može doći do preosjetljivosti na alopurinol, što se najčešće očituje kožnim promjenama. One uključuju makulopapularni osip i svrbež kože koji se javlja u 2-4 \% pacijenata, pa sve do ozbiljnih, po život opasnih manifestacija, kao što je sindrom Steven-Johnson i toksična epidermalna nekroliza. Predisponirajući čimbenici za opasne nuspojave su bubrežna insuficijencija, prisutnost HLA-B*5801 alea (češći je u azijata i crnaca afričkog podrijetla, pa se u njih može prije uvođenja lijeka u liječenje učiniti genetsko testiranje), ženski spol i visoke početne doze alopurinola te istovremeno uzimanje diuretika, a razvijaju se najčešće unutar prva dva mjeseca od početka liječenja ${ }^{1,18,41}$.
Febuksostat je nepurinski inhibitor ksantin oksidaze jer sprječava vezanje purinskih baza za aktivno mjesto enzima, pa djeluje kao urikostatik. Snažniji je od alopurinola (80 mg febuksostata učinkovitije snižava SUA-e od 300 mg alopurinola). Febuskostat se uglavnom metabolizira u jetri, a izlučuje se putem bubrega i dijelom putem jetre i stolice. Njegova prednost je što se može u punoj dozi primjenjivati i u osoba s kroničnom bubrežnom insuficijencijom (bez potrebe prilagode doze do vrijednosti eGF $\geq 30 \mathrm{~mL} / \mathrm{min}$ po 1,73 $\mathrm{m} 2$ ), no potreban je oprez kod ishemijske bolesti srca (stanje nakon infarkta miokarda, nestabilna angina pektoris) kongestivnog zatajenja srca i stanja nakon cerebrovaskularnog inzulta. Novije istraživanje Whitea i sur. pokazalo je da je u pacijenata s gihtom podjednako povećan kardiovaskularni rizik od velikih događaja (smrt zbog kardiovaskularnog događaja, srčani udar, moždani udar, nestabilna angina s potrebom hitnog zahvata revaskularizacije) neovisno o tome jesu li liječeni alopurnolom ili febuksostatom, no u grupi pacijenata koja je liječena febuksostatom bio je veći mortalitet ${ }^{51}$. Kao i alopurinol, ne smije se uzimati zajedno s azatioprinom ili 6-merkaptopurinom. Nuspojave su rijetke i uključuju bubrežnu ili jetrenu reakciju preosjetljivosti te blaže kožne osipe. Ako je pacijent bio preosjetljiv na alopurinool, treba pažljivije uvoditi febuksostat.

Ozbiljnije kožne manifestacije, poput toksične epidermolize i sindroma Steven-Johnson vrlo su rijetke. Prema smjernicama ACR-a iz 2012. godine febuksostat je lijek prvog izbora iz skupine ULT-a, no nadolazeće smjernice ACR-a iz 2020. godine najavljuju alopurinol kao lijek prvog izbora. Prema EULAR smjernicama iz 2016. godine febuksostat je indiciran za pacijente koji razvijaju nuspojave na alopurinol ili se alopurinolom ne može kontrolirati uricemija. Primjenjuje se u početnoj dozi od $80 \mathrm{mg} /$ dan i po potrebi se doza može povisiti na najviše $120 \mathrm{mg} /$ dan, a dozira se jednom dnevno ${ }^{1,18,41}$.

Urikozurici su lijekovi koji smanjuju serumsku razinu urata tako što povećavaju izlučivanje urata putem bubrega, a time i rizik od nefrolitijaze, pa nisu lijek izbora kod uričnih kamenca. Nedjelotvorni su kod klirensa kreatinina $<60 \mathrm{ml} / \mathrm{min}$, a kontraindicirani su kod povišene ekskrecije urata 
urinom (> $700 \mathrm{mg} / 24 \mathrm{~h}$ ). Neophodna je obilna hidratacija za vrijeme njihova uzimanja (najmanje 2 litre/dan) te je poželjna alkalizacija urina. Oni se danas najčešće primjenjuju u kombinaciji s inhibitorima ksantin oksidaze (urikostaticima). Najstariji urikozurik je probenecid i on se danas koristi u pacijenata koji ne reagiraju dobro na alopurinol. Primjenjuje su u inicijalnoj dozi od $250 \mathrm{mg} 2 \mathrm{x} /$ dan te se može povećati do najviše $1 \mathrm{~g} 2$ x/dan. Kod primjene većih doza postoji rizik od neurotoksičnosti. Benzbromaron je zbog svoje hepatotoksičnosti izbačen s europskog tržišta. Lezinurad je selektivni inhibitor URAT1 koji se primjenjuje u kombinaciji s inhibitorima ksantin oksidaze. Losartan kao inhibitor angiotenzin konvertaze i atorvastatin iz grupe statina također imaju u manjoj mjeri urikozurični učinak, pa je njihova primjena vrlo korisna u pacijenata koji imaju komorbiditete uz giht ${ }^{1,18,41}$.

Urikaze su indicirane u pacijenata s uznapredovalim kroničnim gihtom koji je refraktoran na svu postojeću terapiju, kao posljednja opcija. Peglotikaza je pegilirana rekombinantna urikaza proizvedena pomoću genetički modificiranih Escherichia Coli bakterija. Djeluje tako što oksidira uričnu kiselinu u alantion, koji je dobro topljiv i lakše se izlučuje bubrezima ${ }^{1,18,41}$.

Sukob interesa: Autorica Nadica Laktašić Žerjavić izjavljuje kako je predavač za Tevu (Plivu) vezano uz lijek Febuksostat.

\section{LITERATURA}

1. Dalbeth N, Merriman TR, Stamp LK. Gout. Lancet 2016; 388:2039-52.

2. Bardin T, Schiavon F, Punzi L. Crystal arthropathies. In: Bijlsma JWJ, Hachulla E (eds). EULAR Textbook on Rheumatic Diseases. London: BMJ Publishing Group Ltd, 2016;344-72.

3. Zhu Y, Pandya BJ, Choi HK. Prevalence of gout and hyperuricemia in the US general population: the National Health and Nutrition Examination Survey 2007-2008. Arthritis Rheum 2011;63:3136-41.

4. Chen-Xu M, Yokose C, Rai SK, Pillinger MH, Choi HK. Contemporary Prevalence of Gout and Hyperuricemia in the United States and Decadal Trends: The National Health and Nutrition Examination Survey, 2007-2016. Arthritis Rheumatol 2019;71:991-9.

5. Arromdee E, Michet CJ, Crowson CS, O'Fallon WM, Gabriel SE. Epidemiology of gout: is the incidence rising? J Rheumatol 2002;29:2403-6.

6. Dalbeth $\mathrm{N}$, Stamp L. Hyperuricaemia and gout: time for a new staging system? Ann Rheum Dis 2014;73:1598600.
7. Hakoda M, Kasagi F. Increasing trend of asymptomatic hyperuricemia under treatment with urate-lowering drugs in Japan. Mod Rheumatol 2019;29:880-4.

8. Kuo CF, Grainge MJ, Zhang W, Doherty M. Global epidemiology of gout: prevalence, incidence and risk factors. Nat Rev Rheumatol 2015;11:649-62.

9. Schlee S, Bollheimer LC, Bertsch T, Sieber CC, Härle P. Crystal arthritides - gout and calcium pyrophosphate arthritis: Part 1: Epidemiology and pathophysiology. Z Gerontol Geriatr 2018;51:453-60.

10. Martillo MA, Nazzal L, Crittenden DB. The crystallization of monosodium urate. Curr Rheumatol Rep 2014;16: 400-12.

11. Loeb JN. The influence of temperature on the solubility of monosodium urate. Arthritis Rheum 1972;15:189-92.

12. Harris ED Jr, McCroskery PA. The influence of temperature and fibril stability on degradation of cartilage collagen by rheumatoid synovial collagenase. N Engl J Med 1974;290:1-6.

13. Mandal AK, Mount DB. The molecular physiology of uric acid homeostasis. Annu Rev Physiol 2015;77:323-45.

14. Enomoto A, Endou H. Roles of organic anion transporters (OATs) and a urate transporter (URAT1) in the pathophysiology of human disease. Clin Exp Nephrol 2005;9:195-205.

15. Yamamoto T, Moriwaki Y, Takahashi S. Effect of ethanol on metabolism of purine bases (hypoxanthine, xanthine, and uric acid). Clin Chim Acta 2005;356:35-57.

16. McCarthy GT, Green EM, Ogunbona O, Simmonds HA, Fairbanks L, Pountney T et al. A population study of Lesch-Nyhan disease in the UK. Dev Med Child Neurol 2011;53:34-9.

17. Becker MA, Losman MJ, Itkin P, Simkin PA. Gout with superactive phosphoribosylpyrophosphate synthetase due to increased enzyme catalytic rate. J Lab Clin Med 1982;99:495-511.

18. Cronstein BN, Sunkureddi P. Mechanistic aspects of inflammation and clinical management of inflammation in acute gouty arthritis. J Clin Rheumatol 2013;19:19-29.

19. Steiger S, Harper JL. Mechanisms of spontaneous resolution of acute gouty inflammation. Curr Rheumatol Rep 2014;16:392.

20. Yagnik DR, Evans BJ, Florey O, Mason JC, Landis RC, Haskard DO. Macrophage release of transforming growth factor beta1 during resolution of monosodium urate monohydrate crystal-induced inflammation. Arthritis Rheum 2004;50:2273-80.

21. Milas-Ahić J, Prus V, Visević R. [Pathophysiology of gout]. Reumatizam 2012;59:89-92.

22. Towiwat P, Chhana A, Dalbeth N. BMC Musculoskelet Disord 2019;20:140.

23. Dalbeth N, Pool B, Gamble GD, Smith T, Callon KE, McQueen FM et al. Cellular characterization of the gouty tophus: a quantitative analysis. Arthritis Rheum 2010;62:1549-56

24. Schlesinger $\mathrm{N}$, Thiele RG. The pathogenesis of bone erosions in gouty arthritis. Ann Rheum Dis 2010;69:1907-12.

25. Ma CA, Leung YY. Exploring the Link between Uric Acid and Osteoarthritis. Front Med (Lausanne) 2017;4:225.

26. Dalbeth N, Clark B, Gregory K, Gamble G, Sheehan T, Doyle $A$ et al. Mechanisms of bone erosion in gout: a quantitative analysis using plain radiography and computed tomography. Ann Rheum Dis 2009;68:1290-5. 
27. Sapsford M, Gamble GD, Aati O, Knight J, Horne A, Doyle $\mathrm{AJ}$ et al. Relationship of bone erosion with the urate and soft tissue components of the tophus in gout: a dual energy computed tomography study. Rheumatology (Oxford) 2017;56:129-33.

28. Towiwat P, Doyle AJ, Gamble GD, Tan P, Aati O, Horne A et al. Urate crystal deposition and bone erosion in gout: 'inside-out' or 'outside-in'? A dual-energy computed tomography study. Arthritis Res Ther 2016;18:208.

29. Avram Z, Krishnan E. Hyperuricaemia-where nephrology meets rheumatology. Rheumatology (Oxford) 2008;47: 960-4.

30. Halabe A, Sperling O. Uric acid nephrolithiasis. Miner Electrolyte Metab 1994;20:424-31.

31. Conger JD. Acute uric acid nephropathy. Med Clin North Am 1990;74:859-71.

32. Johnson RJ, Nakagawa T, Jalal D, Sánchez-Lozada LG, Kang $\mathrm{DH}$, Ritz E. Uric acid and chronic kidney disease: which is chasing which? Nephrol Dial Transplant 2013;28:2221-8.

33. Zhu Y, Pandya BJ, Choi HK. Comorbidities of gout and hyperuricemia in the US general population: NHANES 2007-2008. Am J Med 2012;125:679-687.e1.

34. Bardin T, Richette P. Impact of comorbidities on gout and hyperuricaemia: an update on prevalence and treatment options. BMC Med 2017;15:123.

35. Maruhashi T, Hisatome I, Kihara Y, Higashi Y. Hyperuricemia and endothelial function: From molecular background to clinical perspectives. Atherosclerosis 2018;278:226-31.

36. Muiesan ML, Agabiti-Rosei C, Paini A, Salvetti M. Uric Acid and Cardiovascular Disease: An Update. Eur Cardiol 2016;11:54-9.

37. Pakpoor J, Seminog OO, Ramagopalan SV, Goldacre MJ. Clinical associations between gout and multiple sclerosis, Parkinson's disease and motor neuron disease: record-linkage studies. BMC Neurol 2015;15:16.

38. Lu N, Dubreuil M, Zhang Y, Neogi T, Rai SK, Ascherio A et al. Gout and the risk of Alzheimer's disease: a population-based, BMI-matched cohort study. Ann Rheum Dis 2016;75:547-51.

39. Hong JY, Lan TY, Tang GJ, Tang CH, Chen TJ, Lin HY. Gout and the risk of dementia: a nationwide population-based cohort study. Arthritis Res Ther 2015;17:139.

40. Campion EW, Glynn RJ, DeLabry LO. Asymptomatic hyperuricemia. Risks and consequences in the Normative Aging Study. Am J Med 1987;82:421-6.
41. Richette P, Doherty M, Pascual E, Barskova V, Becce F, Castañeda-Sanabria J et al. 2016 updated EULAR evidence-based recommendations for the management of gout. Ann Rheum Dis 2017;76:29-42.

42. Schlee S, Bollheimer LC, Bertsch T, Sieber CC, Härle P. Crystal arthritides - gout and calcium pyrophosphate arthritis: Part 2: clinical features, diagnosis and differential diagnostics. Z Gerontol Geriatr 2018;51:579-84.

43. Schlee S, Bollheimer LC, Bertsch T, Sieber CC, Härle P. Crystal arthritides - gout and calcium pyrophosphate arthritis: Part 3: Treatment. Z Gerontol Geriatr 2018;51: 703-10.

44. Shoji A, Yamanaka H, Kamatani N. A retrospective study of the relationship between serum urate level and recurrent attacks of gouty arthritis: evidence for reduction of recurrent gouty arthritis with antihyperuricemic therapy. Arthritis Rheum 2004;51:321-5.

45. Neogi T, Jansen TL, Dalbeth N, Fransen J, Schumacher HR, Berendsen D et al. 2015 Gout classification criteria: an American College of Rheumatology/European League Against Rheumatism collaborative initiative. Ann Rheum Dis 2015;74:1789-98. Erratum in: Ann Rheum Dis 2016; 75:473.

46. Naredo E, lagnocco A. One year in review 2017: ultrasound in crystal arthritis. Clin Exp Rheumatol 2017;35:3627.

47. Jacques $T$, Michelin $P$, Badr S, Nasuto M, Lefebvre G, Larkman N et al. Conventional Radiology in Crystal Arthritis: Gout, Calcium Pyrophosphate Deposition, and Basic Calcium Phosphate Crystals. Radiol Clin North Am 2017;55: 967-84.

48. Buckens CF, Terra MP, Maas M. Computed Tomography and MR Imaging in Crystalline-Induced Arthropathies. Radiol Clin North Am 2017;55:1023-34.

49. Mu Z, Wang W, Wang J, Lv W, Chen Y, Wang F et al. Predictors of poor response to urate-lowering therapy in patients with gout and hyperuricemia: a post-hoc analysis of a multicenter randomized trial. Clin Rheumatol 2019;38:3511-9.

50. Roddy E, Doherty M. Epidemiology of gout. Arthritis Res Ther 2010;12:223.

51. White WB, Saag KG, Becker MA, Borer JS, Gorelick PB, Whelton A, Hunt B, Castillo M, Gunawardhana L; CARES Investigators. Cardiovascular Safety of Febuxostat or Allopurinol in Patients with Gout. N Engl J Med 2018; 378:1200-10. 